\title{
Review
}

Obesity and Metabolic Syndrome

Diabetes Metab J 2013;37:404-414

http://dx.doi.org/10.4093/dmj.2013.37.6.404

pISSN 2233-6079 • eISSN 2233-6087

DIABET\&S \& METABOLISM JOURNAL

\section{Resistin in Rodents and Humans}

\author{
Hyeong Kyu Park ${ }^{1}$, Rexford S. Ahima ${ }^{2}$ \\ ${ }^{1}$ Department of Internal Medicine, Soonchunhyang University College of Medicine, Seoul, Korea, \\ ${ }^{2}$ Division of Endocrinology, Diabetes and Metabolism, and the Institute for Diabetes, Obesity and Metabolism, Department of Medicine, Perelman School of \\ Medicine at the University of Pennsylvania, Philadelphia, PA, USA
}

\begin{abstract}
Obesity is characterized by excess accumulation of lipids in adipose tissue and other organs, and chronic inflammation associated with insulin resistance and an increased risk of type 2 diabetes. Obesity, type 2 diabetes, and cardiovascular diseases are major health concerns. Resistin was first discovered as an adipose-secreted hormone (adipokine) linked to obesity and insulin resistance in rodents. Adipocyte-derived resistin is increased in obese rodents and strongly related to insulin resistance. However, in contrast to rodents, resistin is expressed and secreted from macrophages in humans and is increased in inflammatory conditions. Some studies have also suggested an association between increased resistin levels and insulin resistance, diabetes and cardiovascular disease. Genetic studies have provided additional evidence for a role of resistin in insulin resistance and inflammation. Resistin appears to mediate the pathogenesis of atherosclerosis by promoting endothelial dysfunction, vascular smooth muscle cell proliferation, arterial inflammation, and formation of foam cells. Indeed, resistin is predictive of atherosclerosis and poor clinical outcomes in patients with coronary artery disease and ischemic stroke. There is also growing evidence that elevated resistin is associated with the development of heart failure. This review will focus on the biology of resistin in rodents and humans, and evidence linking resistin with type 2 diabetes, atherosclerosis, and cardiovascular disease.
\end{abstract}

Keywords: Adipocytes; Atherosclerosis; Cardiovascular diseases; Diabetes mellitus, type 2; Inflammation; Insulin resistance; Macrophages; Obesity; Polymorphism, genetic; Resistin

\section{INTRODUCTION}

The prevalence of obesity has increased worldwide and is associated with increased risk of type 2 diabetes mellitus (T2DM), cardiovascular disease (CVD), sleep apnea, cancer, fatty liver, and other diseases. It has become clear that obesity promotes a state of chronic inflammation in white adipose tissue (WAT), which leads to insulin resistance. Obesity results in excessive lipid accumulation in adipocytes and macrophages in WAT, which plays an active role in the development of insulin resistance through the release of free fatty acids, proinflammatory cytokines, and adipokines [1]. Adipose tissue secretes adipokines that play major roles in metabolism, immunity, and inflammation. Resistin is secreted primarily by adipocytes in rodents and was initially proposed as a link between obesity and insulin resistance [2]. In humans, resistin is mainly secreted by macrophages [3], suggesting that resistin is linked to inflammation. Obesity, T2DM, and CVD have been recently recognized as chronic inflammatory disorders which may be connected to proinflammatory cytokines as well as adipokines such as resistin [4]. In this review, we will discuss the biology of resistin in rodents and humans, and focus on the evolving roles of resistin in atherosclerosis and CVD in humans.

\section{REGULATION OF RESISTIN SYNTHESIS AND SECRETION}

Resistin is a cysteine-rich protein which was discovered using a screening strategy for genes down-regulated in mouse adipocytes by thiazolidinedione (TZD) drugs [2]. In rodents, re-
Corresponding author: Rexford S. Ahima

Division of Endocrinology, Diabetes and Metabolism, and the Institute for Diabetes, Obesity and Metabolism, Department of Medicine, Perelman School of Medicine at the University of Pennsylvania, 12-104 Translational Research Center, 3400 Civic Center Blvd, Bldg 421, Philadelphia, PA 19104, USA

E-mail: ahima@mail.med.upenn.edu
This is an Open Access article distributed under the terms of the Creative Commons Attribution Non-Commercial License (http://creativecommons.org/licenses/by-nc/3.0/) which permits unrestricted non-commercial use, distribution, and reproduction in any medium, provided the original work is properly cited.

Copyright (C) 2013 Korean Diabetes Association

http://e-dmj.org 
sistin is primarily expressed in mature white adipocytes. Mouse resistin expression is reduced in 3T3-L1 adipocytes by TZD drugs [5,6] and insulin [5,7]. In contrast, high glucose up-regulates resistin expression in adipocytes $[5,8]$. There were also conflicting results showing insulin can stimulate resistin secretion in mouse adipocytes [9-11]. Resistin expression in mouse adipocytes is suppressed by inflammatory cytokines, e.g., tumor necrosis factor $\alpha$ (TNF- $\alpha$ ), [5,12]. Unlike rodents, human resistin is expressed in macrophages and is induced by TNF- $\alpha$ $[13,14]$. The lack of human resistin expression in adipocytes may be due to loss of a genomic binding site for the nuclear receptor peroxisome proliferator-activated receptor $\gamma$ that normally controls resistin gene (retn) expression in mouse adipocytes [15]. Dietary intake has a significant effect on the regulation of resistin in rodents. The expression of resistin is decreased in the adipose tissue during fasting, and tends to increase upon refeeding in mice $[2,8,16]$. Serum resistin is also reduced in fasted mice. Diet-induced obese mice have elevated circulating resistin levels, however, resistin mRNA expression is suppressed in adipose tissue in these mice. Similarly, serum resistin is increased in $o b / o b$ mice while resistin mRNA expression is reduced [16,17].

Resistin circulates in two distinct forms in mice. A disulfidelinked hexamer of resistin is the major form, but a smaller trimeric protein is also detected. The low molecular weight form of trimer is shown to be more bioactive, significantly decreasing hepatic insulin sensitivity during pancreatic clamp study [18]. However, oligomerization is required for the inhibitory action of resistin on glucose uptake in mouse cardiomyocytes [19]. In humans, there are also different molecular isoforms of circulating resistin such as trimeric and oligomeric forms, and the oligomeric form of human resistin is considered to have a more potent effect on the stimulation of proinflammatory cytokines [20-22].

\section{RESISTIN IN GLUCOSE HOMEOSTASIS IN RODENTS}

Several lines of evidence support a role of resistin in glucose metabolism in rodents. Circulating levels of resistin were higher in obese mice, and the administration of recombinant resistin in normal mice impaired glucose tolerance and insulin action. Furthermore, neutralization of resistin with antiresistin antibody improved insulin sensitivity in diet-induced obese mice [2]. Both central and peripheral administration of recom- binant resistin, or transgenic overexpression of resistin induced hepatic insulin resistance in mice [2,23-25]. Conversely, knockdown or deletion of resistin increased hepatic insulin sensitivity in mice on high-fat diet, and in muscle and WAT in $o b / o b$ mice, leading to a decrease in glucose production and an increase in glucose uptake from peripheral tissue [26,27]. Resistin knockout mice showed low glucose levels after fasting, associated with a decrease in expression of gluconeogenic enzymes in liver [26]. Treatment of 3T3-L1 adipocytes, murine cardiomyocytes, and cultured skeletal muscle cells with murine resistin decreased insulin-stimulated glucose uptake into the cells $[2,19,28,29]$. All of these findings suggest resistin plays an important role in insulin sensitivity in rodents.

Nevertheless, the resistin receptor or the intracellular signaling pathways of resistin have not yet been clearly identified. Recent studies proposed an isoform of decorin or tyrosine kinase-like orphan receptor 1 as functional resistin receptors which may regulate WAT expansion or modulate glucose homeostasis in rodents [30,31]. Murine resistin has been demonstrated to decrease the phosphorylation of AMP-activated kinase (AMPK) in liver, skeletal muscle, and WAT [24,26,32]. Inhibition of resistin, conversely, led to an increase in the phosphorylation of AMPK which is involved in glucose homeostasis. Resistin interferes with multiple steps involved in the insulin signaling cascade, including phosphorylation of insulin receptor substrates, activation of phosphatidylinositol3-kinase (PI3K) and protein kinase B/Akt in liver, muscle, and WAT $[24,32,33]$. Resistin treatment in rodents induces the expression of suppressor of cytokine signaling-3, a known inhibitor of insulin signaling, in liver, muscle, and WAT [17,27,3335]. Considering adipocyte-derived resistin is linked to insulin resistance in rodents, the potential that rodent data may be applicable to human biology has led to much scientific research.

\section{HUMAN RESISTIN IN OBESITY, INSULIN RESISTANCE AND DIABETES}

Resistin is predominantly expressed in peripheral blood mononuclear cells (PBMCs), and its expression increases as the cells differentiate into macrophages in humans $[3,14,36]$. As in murine resistin, TZD drugs down-regulated the expression of human resistin in macrophages or reduced serum resistin levels $[3,14,37]$. Resistin expression is also found in the nonadipocyte stromal vascular fraction in WAT, fibrotic liver, and atherosclerotic lesions, indicating that macrophages are the main 
source of resistin in humans [38-41]. Indeed, obese individuals who are likely to have greater infiltration of macrophages in adipose tissue showed increased expression of resistin in adipose tissue samples or had higher circulating levels of resistin than in lean individuals [36,42]. Studies of obese subjects undergoing weight reduction through diet or bariatric surgery have shown inconsistent results. Serum resistin levels were reduced, or not changed, despite weight loss in obese subjects [43-45]. There were also several reports that serum resistin levels are not associated with the parameters of obesity or insulin resistance [46-48]. However, resistin levels have been associated with visceral, intrathoracic, and pericardial fat in a cross-sectional study [49].

Given the close relationship of murine resistin and insulin resistance, numerous clinical studies have examined a possible relationship of resistin and insulin resistance in obese people with or without diabetes. Since obesity and T2DM are both associated with chronic inflammation in WAT, and resistin is mainly produced by macrophages in humans, it is possible that hyperresistinemia is a contributing factor to these pathophysiological states. However, studies relating human resistin to insulin resistance, or T2DM have shown conflicting results [35,46,47,50-52]. Qatanani et al. [53] generated transgenic mice expressing human resistin via a macrophage promoter and bred them with resistin knockout mice. The humanized resistin mice developed WAT inflammation and insulin resistance, demonstrating that human resistin may link inflammatory responses and glucose homeostasis. This is consistent with prospective case-control studies showing that people with elevated baseline levels of resistin have significantly increased risk of developing T2DM even after adjusting for other risk factors $[54,55]$.

\section{RESISTIN POLYMORPHISMS IN INSULIN RESISTANCE AND ATHEROSCLEROSIS}

Epidemiological studies also suggest that resistin plays a role in insulin resistance and T2DM in humans. Several single-nucleotide polymorphisms (SNPs) have been demonstrated to be associated with elevated resistin levels, and up to two-thirds of the variation of serum resistin levels may be attributable to genetic factors [56]. The $-638 \mathrm{G}>\mathrm{A},-420 \mathrm{C}>\mathrm{G}$, and $-358 \mathrm{G}>\mathrm{A}$ polymorphisms in the promoter region of human resistin gene (RETN) were associated with resistin levels in Japanese obese individuals [57]. In a Japanese population, the G/G genotype at
SNP -420 in RETN was associated with susceptibility to T2DM and also was correlated with monocyte resistin expression and with increased serum resistin levels [58,59]. Moreover, a crosssectional analysis of 2,078 Japanese subjects showed that plasma resistin was associated with SNP -420 and also correlated with insulin resistance [60]. The $-420 \mathrm{G}$ and $-537 \mathrm{~A}$ alleles were associated with increased resistin levels but not with T2DM in a Korean population [61]. In the 5-year prospective study from a Chinese subjects, both $-420 \mathrm{G}$ and $+62 \mathrm{~A}$ alleles were significant predictors of glycemic progression [62]. Although -420 C> G SNP associated with high resistin levels appears to be related to T2DM in many studies of Asian populations, the data in Caucasian populations have been conflicting [55]. An Italian study showed that the presence of -420 C/G SNP in RETN is associated with increased obesity and metabolic syndrome but not with resistin levels [63]. An American cohort of Caucasian nondiabetic subjects has shown an association of $-420 \mathrm{G}$ allele with resistin level, but no association with insulin resistance [64]. In the Framingham Offspring Study cohort of 2,531 participants, it has been shown that not $-420 \mathrm{C}>\mathrm{G}$ SNP but SNPs in the 3' region of RETN are associated with resistin levels [65]. However, El-Shal et al. [66] have recently demonstrated that both $-420 \mathrm{C}>\mathrm{G}$ and $+299 \mathrm{G}>\mathrm{A}$ SNP were significantly associated with resistin level, obesity, and insulin resistance in Egyptian obese subjects.

The role of human resistin in the pathogenesis of atherosclerosis is also gaining research attention. Tang et al. [67] have shown that $-420 \mathrm{C} / \mathrm{G}$ SNP in RETN is associated with an increased risk of coronary artery disease (CAD) in a Chinese population. In contrast, a couple of studies of the -420 variant in Europeans and Caucasians found no correlation with carotid and coronary atherosclerosis, respectively $[63,64]$. The discrepancy in the results among populations might be attributable to ethnic differences.

\section{ROLE OF HUMAN RESISTIN IN INFLAMMATION}

Murine and human resistin share about $60 \%$ sequence homology. As noted before, resistin levels decrease with TZD treatment in both humans and rodents. Unlike murine resistin, human resistin is highly expressed in macrophages, and robustly induced in response to various proinflammatory stimuli such as lipopolysaccharide (LPS), TNF- $\alpha$, interleukin (IL)-6, IL- $1 \beta$, and resistin itself, suggesting a role for resistin in inflam- 
mation in humans $[13,14,68]$. Furthermore, resistin has been shown to up-regulate the expression of proinflammatory cytokines such as TNF- $\alpha$, IL- 6 , IL-12, or monocyte chemoattractant protein (MCP)-1 in PBMC, macrophages, and hepatic stellate cells, mediated through the nuclear factor- $\mathrm{\kappa B}$ signaling pathway $[39,68,69]$. In line with these findings, circulating resistin levels correlate with inflammatory and fibrinolytic markers such as C-reactive protein (CRP), TNF- $\alpha$, IL-6, or plasminogen activator inhibitor (PAI)-1 in subjects with T2DM, coronary atherosclerosis, chronic kidney disease, rheumatoid arthritis (RA), and sepsis [14,46,48,70-73] as well as in general population [48,60,74-78]. Increased resistin levels have been observed in patients with RA and inflammatory bowel disease and shown to be associated with disease activity $[22,72,78]$. In addition, circulating resistin levels were elevated in patients with severe sepsis and acute pancreatitis. Interestingly, resistin was related with disease severity in patients with severe sepsis as well as acute pancreatitis, and also predicted an unfavorable outcome in nonseptic critically ill patients $[73,79,80]$.

It is noteworthy that numerous inflammatory factors upregulated by human resistin are known to be involved in the development of insulin resistance. Therefore, it is possible that resistin induced by inflammation may play a role in the development of insulin resistance in humans. To address this issue, Park et al. [81] generated mice lacking murine resistin but transgenic for a bacterial artificial chromosome containing human resistin (BAC-Retn), whose expression was similar to levels in humans. LPS increased serum resistin levels in this model, and resulted in mild hypoglycemia compared with mice lacking murine and human resistin. In addition, the BAC-Retn mice developed hepatic insulin resistance under chronic endotoxemia, accompanied by inflammation in liver and skeletal muscle, supporting the role of resistin in the pathophysiology of inflammation-induced insulin resistance in humans [81]. A recent study suggested that human resistin competes with LPS for binding to Toll-like receptor 4 (TLR4) which could mediate some of the proinflammatory effects of resistin [82], however, it is unknown whether TLR4 is the predominant resistin receptor in humans.

\section{HUMAN RESISTIN IN ATHEROSCLEROSIS}

Given the evidence that resistin is found in human atherosclerotic lesions and affects vascular endothelial function $[40,41,83]$, it is possible resistin is involved in the development of athero- sclerosis and CVD. Treatment of human resistin increased proliferation and migration of human endothelial cells (ECs) and vascular smooth muscle cells (VSMCs). Cell proliferation and migration induced by resistin in both EC and VSMC appears to be mediated through the extracellular signal-regulated kinase, PI3K, or p38 mitogen-activated protein kinase signaling pathways [84-86]. Resistin was also shown to attenuate the ability of insulin signaling, inhibit endothelial nitric-oxide synthase, and increase oxidative stress in human aortic and coronary artery EC $[86,87]$. In addition, resistin up-regulated the expression of adhesion molecules such as intercellular adhesion molecule-1, vascular cell adhesion molecule-1, P-selectin, and fractalkine, and also increased proinflammatory factors such as MCP-1, PAI-1, endothelin-1, matrix metalloproteinases, and vascular endothelial growth factor receptors, and, thereby, promoted monocyte adhesion in vascular EC $[17,41,83,84,88,89]$. Furthermore, resistin was expressed in human atheroma samples, and increased lipid accumulation through the up-regulation of CD36 expression and an increase in cholesteryl ester deposition in human macrophages, suggesting a role of resistin as a modulator for macrophage to foam cell transformation $[40,41,90,91]$. In addition, resistin has been shown to induce a prothrombotic phenotype by upregulating tissue factor expression in human coronary artery EC $[92,93]$. Taken together, these findings indicate that resistin may contribute to EC dysfunction, VSMC proliferation, arterial inflammation, and accumulation of cholesterol in macrophages, suggesting that resistin plays an important role in the pathogenesis and progression of atherosclerosis in humans.

\section{CLINICAL IMPLICATIONS OF RESISTIN IN CVD}

There is the growing evidence that resistin is involved in the pathogenesis of CVD. Reilly et al. [48] showed that elevated resistin levels were predictive of coronary atherosclerosis, independent of CRP, in asymptomatic individuals. Resistin was associated with the presence and severity of CAD in patients undergoing coronary angiography and those with stable CAD $[94,95]$. Moreover, resistin predicted restenosis after coronary artery stenting and was an independent predictor of major adverse cardiovascular events in patients with CAD [96-99]. In Korean patients with acute myocardial infarction (MI), resistin was an independent predictor of all cause mortality during 
the mean follow-up period of 12 months [100]. A European study found that high plasma resistin levels were associated with an increased risk of MI but not with risk of ischemic stroke in healthy subjects, even after adjustment for established cardiovascular risk factors including CRP [101]. In regard to the risk of ischemic stroke, a cross-sectional study from Japan and two nested case-control studies from Europe and United States showed that resistin was significantly associated with ischemic stroke among healthy individuals [102-104]. Higher resistin levels were also associated with poorer prognosis in patients with CAD or atherothrombotic stroke [99,105-107]. More recently, an analysis of 2,313 diabetic patients of European ancestry from two cross-sectional and two prospective studies showed that high serum resistin was a risk factor for CVD and all cause mortality in patients with T2DM [108]. Interestingly, resistin was also shown to be associated with vascular inflammation measured using 18F-fluorodeoxyglucose-positron emission tomography among healthy individuals [109]. De- spite some studies showing no association between resistin and CVD [110-112], a number of animal and clinical studies are strongly supporting the idea that resistin is a potential mediator of atherosclerosis and CAD in humans.

Several animal studies have investigated the effects of resistin on cardiomyocytes. Murine resistin directly reduced both basal and insulin-stimulated glucose uptake in mouse cardiomyocytes [19]. Murine resistin was shown to be up-regulated by mechanical stretch and the overexpression of resistin depressed cardiac contractility, promoting cardiac hypertrophy in rat cardiomyocytes [113,114], suggesting resistin may affect cardiac function in animal models. Regarding the effects of human resistin on cardiomyocytes, however, very few studies have been reported. Human resistin inhibited insulin-stimulated glucose uptake in isolated mouse cardiomyocytes [19]. Preconditioning with recombinant human resistin prior to ischemia significantly impaired contractile recovery during reperfusion and stimulated cardiac TNF- $\alpha$ secretion in isolat-

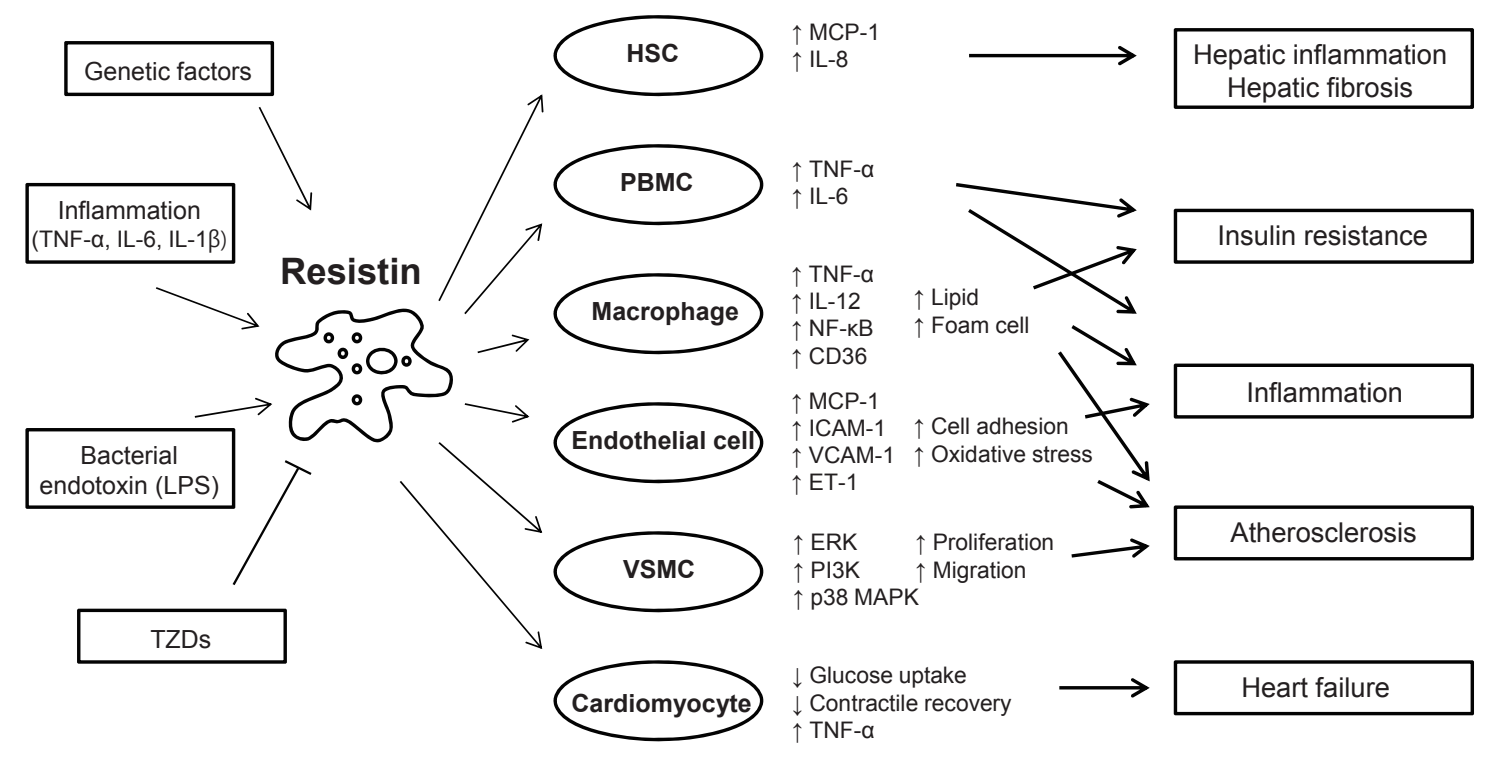

Fig. 1. Roles of resistin in inflammation, glucose homeostasis, and cardiovascular diseases. Resistin is induced in response to various stimuli, including proinflammatory cytokines, lipopolysaccharide (LPS), and genetically determined factors. Resistin targets several types of cells, promoting inflammation, insulin resistance, and atherosclerosis. Resistin is up-regulated and secreted from PBMC and macrophages, and in turn, acts on these cells, leading to the development of insulin resistance and enhancing inflammatory processes through activation of nuclear factor (NF)- $\mathrm{kB}$. Resistin contributes to the pathogenesis of atherosclerosis by disrupting vascular endothelial cellular function, and increasing proliferation of smooth muscle cells, and foam cell transformation. Resistin directly affects the function of cardiomyocytes predisposing to myocardial injury. Adapted from Schwartz et al. Trends Endocrinol Metab 2011;22:259-65, with permission from Elsevier [55]. HSC, hepatic stellate cell; MCP, monocyte chemoattractant protein; IL, interleukin; TNF, tumor necrosis factor; PBMC, peripheral blood mononuclear cell; ICAM, intercellular adhesion molecule; VCAM, vascular cell adhesion molecule; ET, endothelin; VSMC, vascular smooth muscle cell; ERK, extracellular signal-regulated kinase; PI3K, phosphatidylinositol-3-kinase; MAPK, mitogen-activated protein kinase; TZD, thiazolidinedione. 
ed rat hearts, suggesting human resistin has direct cardiac actions [115]. Emerging evidence suggests that elevated resistin is associated with the development of heart failure (HF). Takeishi et al. [116] have found that resistin is correlated with the severity of $\mathrm{HF}$ and predicts adverse cardiac events in patients with established HF. In addition, two large cohort studies have shown that high resistin is independently associated with new-onset HF, even after adjusting for known risk factors [117-119]. However, the causal role of resistin in HF is unclear and needs further investigation.

\section{CONCLUSIONS}

Resistin was initially described as a link between obesity and insulin resistance in rodents. In rodents, resistin is almost exclusively expressed in white adipocytes, whereas human resistin is predominantly expressed in macrophages. The phenotypes of humanized resistin transgenic mice suggest similar roles of murine and human resistin in insulin resistance. Studies in humanized resistin transgenic mice and epidemiological data also suggest that human resistin is a potential mediator between inflammation, and insulin resistance and atherosclerosis (Fig. 1). The identification of the resistin receptor and specific signaling mechanisms will help address crucial questions concerning the biology of resistin in health and disease. Insights into the pathophysiological role of resistin will facilitate the development of novel diagnostic and treatment tools for diabetes, and inflammatory and CVDs.

\section{CONFLICTS OF INTEREST}

No potential conflict of interest relevant to this article was reported.

\section{ACKNOWLEDGMENTS}

This work was supported by grants P01-DK-049210 and P30DK-19525 from the National Institutes of Health, USA.

\section{REFERENCES}

1. Kahn SE, Hull RL, Utzschneider KM. Mechanisms linking obesity to insulin resistance and type 2 diabetes. Nature 2006; 444:840-6.

2. Steppan CM, Bailey ST, Bhat S, Brown EJ, Banerjee RR, Wright
CM, Patel HR, Ahima RS, Lazar MA. The hormone resistin links obesity to diabetes. Nature 2001;409:307-12.

3. Patel L, Buckels AC, Kinghorn IJ, Murdock PR, Holbrook JD, Plumpton C, Macphee CH, Smith SA. Resistin is expressed in human macrophages and directly regulated by PPAR gamma activators. Biochem Biophys Res Commun 2003;300:472-6.

4. Hotamisligil GS. Inflammation and metabolic disorders. Nature 2006;444:860-7.

5. Shojima N, Sakoda H, Ogihara T, Fujishiro M, Katagiri H, Anai M, Onishi Y, Ono H, Inukai K, Abe M, Fukushima Y, Kikuchi M, Oka Y, Asano T. Humoral regulation of resistin expression in 3T3-L1 and mouse adipose cells. Diabetes 2002; 51:1737-44.

6. Hartman HB, Hu X, Tyler KX, Dalal CK, Lazar MA. Mechanisms regulating adipocyte expression of resistin. J Biol Chem 2002;277:19754-61.

7. Haugen F, Jorgensen A, Drevon CA, Trayhurn P. Inhibition by insulin of resistin gene expression in 3T3-L1 adipocytes. FEBS Lett 2001;507:105-8.

8. Rajala MW, Lin Y, Ranalletta M, Yang XM, Qian H, Gingerich R, Barzilai N, Scherer PE. Cell type-specific expression and coregulation of murine resistin and resistin-like molecule-alpha in adipose tissue. Mol Endocrinol 2002;16:1920-30.

9. Zhong Q, Lin CY, Clarke KJ, Kemppainen RJ, Schwartz DD, Judd RL. Endothelin-1 inhibits resistin secretion in 3T3-L1 adipocytes. Biochem Biophys Res Commun 2002;296:383-7.

10. Wolfing B, Neumeier M, Buechler C, Aslanidis C, Scholmerich J, Schaffler A. Interfering effects of insulin, growth hormone and glucose on adipokine secretion. Exp Clin Endocrinol Diabetes 2008;116:47-52.

11. Pang SS, Le YY. Role of resistin in inflammation and inflammation-related diseases. Cell Mol Immunol 2006;3:29-34.

12. Fasshauer M, Klein J, Neumann S, Eszlinger M, Paschke R. Tumor necrosis factor alpha is a negative regulator of resistin gene expression and secretion in 3T3-L1 adipocytes. Biochem Biophys Res Commun 2001;288:1027-31.

13. Kaser S, Kaser A, Sandhofer A, Ebenbichler CF, Tilg H, Patsch JR. Resistin messenger-RNA expression is increased by proinflammatory cytokines in vitro. Biochem Biophys Res Commun 2003;309:286-90.

14. Lehrke M, Reilly MP, Millington SC, Iqbal N, Rader DJ, Lazar MA. An inflammatory cascade leading to hyperresistinemia in humans. PLoS Med 2004;1:e45.

15. Tomaru T, Steger DJ, Lefterova MI, Schupp M, Lazar MA. Adipocyte-specific expression of murine resistin is mediated 
by synergism between peroxisome proliferator-activated receptor gamma and CCAAT/enhancer-binding proteins. J Biol Chem 2009;284:6116-25.

16. Rajala MW, Qi Y, Patel HR, Takahashi N, Banerjee R, Pajvani UB, Sinha MK, Gingerich RL, Scherer PE, Ahima RS. Regulation of resistin expression and circulating levels in obesity, diabetes, and fasting. Diabetes 2004;53:1671-9.

17. Barnes KM, Miner JL. Role of resistin in insulin sensitivity in rodents and humans. Curr Protein Pept Sci 2009;10:96-107.

18. Patel SD, Rajala MW, Rossetti L, Scherer PE, Shapiro L. Disulfide-dependent multimeric assembly of resistin family hormones. Science 2004;304:1154-8.

19. Graveleau C, Zaha VG, Mohajer A, Banerjee RR, DudleyRucker N, Steppan CM, Rajala MW, Scherer PE, Ahima RS, Lazar MA, Abel ED. Mouse and human resistins impair glucose transport in primary mouse cardiomyocytes, and oligomerization is required for this biological action. J Biol Chem 2005;280:31679-85.

20. Gerber M, Boettner A, Seidel B, Lammert A, Bar J, Schuster E, Thiery J, Kiess W, Kratzsch J. Serum resistin levels of obese and lean children and adolescents: biochemical analysis and clinical relevance. J Clin Endocrinol Metab 2005;90:4503-9.

21. Aruna B, Islam A, Ghosh S, Singh AK, Vijayalakshmi M, Ahmad F, Ehtesham NZ. Biophysical analyses of human resistin: oligomer formation suggests novel biological function. Biochemistry 2008;47:12457-66.

22. Filkova M, Haluzik M, Gay S, Senolt L. The role of resistin as a regulator of inflammation: implications for various human pathologies. Clin Immunol 2009;133:157-70.

23. Rajala MW, Obici S, Scherer PE, Rossetti L. Adipose-derived resistin and gut-derived resistin-like molecule-beta selectively impair insulin action on glucose production. J Clin Invest 2003; 111:225-30.

24. Muse ED, Obici S, Bhanot S, Monia BP, McKay RA, Rajala MW, Scherer PE, Rossetti L. Role of resistin in diet-induced hepatic insulin resistance. J Clin Invest 2004;114:232-9.

25. Li FP, He J, Li ZZ, Luo ZF, Yan L, Li Y. Effects of resistin expression on glucose metabolism and hepatic insulin resistance. Endocrine 2009;35:243-51.

26. Banerjee RR, Rangwala SM, Shapiro JS, Rich AS, Rhoades B, Qi Y, Wang J, Rajala MW, Pocai A, Scherer PE, Steppan CM, Ahima RS, Obici S, Rossetti L, Lazar MA. Regulation of fasted blood glucose by resistin. Science 2004;303:1195-8.

27. Qi Y, Nie Z, Lee YS, Singhal NS, Scherer PE, Lazar MA, Ahima RS. Loss of resistin improves glucose homeostasis in leptin deficiency. Diabetes 2006;55:3083-90.

28. Palanivel R, Maida A, Liu Y, Sweeney G. Regulation of insulin signalling, glucose uptake and metabolism in rat skeletal muscle cells upon prolonged exposure to resistin. Diabetologia 2006;49:183-90.

29. Fan HQ, Gu N, Liu F, Fei L, Pan XQ, Guo M, Chen RH, Guo XR. Prolonged exposure to resistin inhibits glucose uptake in rat skeletal muscles. Acta Pharmacol Sin 2007;28:410-6.

30. Daquinag AC, Zhang Y, Amaya-Manzanares F, Simmons PJ, Kolonin MG. An isoform of decorin is a resistin receptor on the surface of adipose progenitor cells. Cell Stem Cell 2011;9: 74-86.

31. Sanchez-Solana B, Laborda J, Baladron V. Mouse resistin modulates adipogenesis and glucose uptake in 3T3-L1 preadipocytes through the ROR1 receptor. Mol Endocrinol 2012;26: 110-27.

32. Satoh H, Nguyen MT, Miles PD, Imamura T, Usui I, Olefsky JM. Adenovirus-mediated chronic "hyper-resistinemia" leads to in vivo insulin resistance in normal rats. J Clin Invest 2004; 114:224-31.

33. Steppan CM, Wang J, Whiteman EL, Birnbaum MJ, Lazar MA. Activation of SOCS-3 by resistin. Mol Cell Biol 2005;25:156975.

34. Muse ED, Lam TK, Scherer PE, Rossetti L. Hypothalamic resistin induces hepatic insulin resistance. J Clin Invest 2007; 117:1670-8.

35. Lazar MA. Resistin- and Obesity-associated metabolic diseases. Horm Metab Res 2007;39:710-6.

36. Savage DB, Sewter CP, Klenk ES, Segal DG, Vidal-Puig A, Considine RV, O'Rahilly S. Resistin / Fizz3 expression in relation to obesity and peroxisome proliferator-activated receptor-gamma action in humans. Diabetes 2001;50:2199-202.

37. Samaha FF, Szapary PO, Iqbal N, Williams MM, Bloedon LT, Kochar A, Wolfe ML, Rader DJ. Effects of rosiglitazone on lipids, adipokines, and inflammatory markers in nondiabetic patients with low high-density lipoprotein cholesterol and metabolic syndrome. Arterioscler Thromb Vasc Biol 2006;26: 624-30.

38. Fain JN, Cheema PS, Bahouth SW, Lloyd Hiler M. Resistin release by human adipose tissue explants in primary culture. Biochem Biophys Res Commun 2003;300:674-8.

39. Bertolani C, Sancho-Bru P, Failli P, Bataller R, Aleffi S, DeFranco R, Mazzinghi B, Romagnani P, Milani S, Gines P, Colmenero J, Parola M, Gelmini S, Tarquini R, Laffi G, Pinzani M, Marra F. Resistin as an intrahepatic cytokine: overexpres- 
sion during chronic injury and induction of proinflammatory actions in hepatic stellate cells. Am J Pathol 2006;169:2042-53.

40. Burnett MS, Lee CW, Kinnaird TD, Stabile E, Durrani S, Dullum MK, Devaney JM, Fishman C, Stamou S, Canos D, Zbinden S, Clavijo LC, Jang GJ, Andrews JA, Zhu J, Epstein SE. The potential role of resistin in atherogenesis. Atherosclerosis 2005;182:241-8.

41. Jung HS, Park KH, Cho YM, Chung SS, Cho HJ, Cho SY, Kim SJ, Kim SY, Lee HK, Park KS. Resistin is secreted from macrophages in atheromas and promotes atherosclerosis. Cardiovasc Res 2006;69:76-85.

42. Pagano C, Marin O, Calcagno A, Schiappelli P, Pilon C, Milan G, Bertelli M, Fanin E, Andrighetto G, Federspil G, Vettor R. Increased serum resistin in adults with prader-willi syndrome is related to obesity and not to insulin resistance. J Clin Endocrinol Metab 2005;90:4335-40.

43. Azuma K, Katsukawa F, Oguchi S, Murata M, Yamazaki H, Shimada A, Saruta T. Correlation between serum resistin level and adiposity in obese individuals. Obes Res 2003;11:997-1001.

44. Moschen AR, Molnar C, Wolf AM, Weiss H, Graziadei I, Kaser S, Ebenbichler CF, Stadlmann S, Moser PL, Tilg H. Effects of weight loss induced by bariatric surgery on hepatic adipocytokine expression. J Hepatol 2009;51:765-77.

45. de Luis DA, Terroba MC, Cuellar L, Conde R, Primo D, Aller R, Sagrado MG, Izaola O. Resistin levels in morbid obese patients following the biliopancreatic diversion surgery. Horm Metab Res 2011;43:205-8.

46. McTernan PG, Fisher FM, Valsamakis G, Chetty R, Harte A, McTernan CL, Clark PM, Smith SA, Barnett AH, Kumar S. Resistin and type 2 diabetes: regulation of resistin expression by insulin and rosiglitazone and the effects of recombinant resistin on lipid and glucose metabolism in human differentiated adipocytes. J Clin Endocrinol Metab 2003;88:6098-106.

47. Lee JH, Chan JL, Yiannakouris N, Kontogianni M, Estrada E, Seip R, Orlova C, Mantzoros CS. Circulating resistin levels are not associated with obesity or insulin resistance in humans and are not regulated by fasting or leptin administration: crosssectional and interventional studies in normal, insulin-resistant, and diabetic subjects. J Clin Endocrinol Metab 2003;88: 4848-56.

48. Reilly MP, Lehrke M, Wolfe ML, Rohatgi A, Lazar MA, Rader DJ. Resistin is an inflammatory marker of atherosclerosis in humans. Circulation 2005;111:932-9.

49. Jain SH, Massaro JM, Hoffmann U, Rosito GA, Vasan RS, Raji A, O’Donnell CJ, Meigs JB, Fox CS. Cross-sectional associa- tions between abdominal and thoracic adipose tissue compartments and adiponectin and resistin in the Framingham Heart Study. Diabetes Care 2009;32:903-8.

50. Youn BS, Yu KY, Park HJ, Lee NS, Min SS, Youn MY, Cho YM, Park YJ, Kim SY, Lee HK, Park KS. Plasma resistin concentrations measured by enzyme-linked immunosorbent assay using a newly developed monoclonal antibody are elevated in individuals with type 2 diabetes mellitus. J Clin Endocrinol Metab 2004;89:150-6.

51. Hivert MF, Sullivan LM, Fox CS, Nathan DM, D'Agostino RB Sr, Wilson PW, Meigs JB. Associations of adiponectin, resistin, and tumor necrosis factor-alpha with insulin resistance. J Clin Endocrinol Metab 2008;93:3165-72.

52. Tsiotra PC, Tsigos C, Anastasiou E, Yfanti E, Boutati E, Souvatzoglou E, Kyrou I, Raptis SA. Peripheral mononuclear cell resistin mRNA expression is increased in type 2 diabetic women. Mediators Inflamm 2008;2008:892864.

53. Qatanani M, Szwergold NR, Greaves DR, Ahima RS, Lazar MA. Macrophage-derived human resistin exacerbates adipose tissue inflammation and insulin resistance in mice. J Clin Invest 2009.

54. Chen BH, Song Y, Ding EL, Roberts CK, Manson JE, Rifai N, Buring JE, Gaziano JM, Liu S. Circulating levels of resistin and risk of type 2 diabetes in men and women: results from two prospective cohorts. Diabetes Care 2009;32:329-34.

55. Schwartz DR, Lazar MA. Human resistin: found in translation from mouse to man. Trends Endocrinol Metab 2011;22: 259-65.

56. Menzaghi C, Coco A, Salvemini L, Thompson R, De Cosmo S, Doria A, Trischitta V. Heritability of serum resistin and its genetic correlation with insulin resistance-related features in nondiabetic Caucasians. J Clin Endocrinol Metab 2006;91: 2792-5.

57. Azuma K, Oguchi S, Matsubara Y, Mamizuka T, Murata M, Kikuchi H, Watanabe K, Katsukawa F, Yamazaki H, Shimada A, Saruta T. Novel resistin promoter polymorphisms: association with serum resistin level in Japanese obese individuals. Horm Metab Res 2004;36:564-70.

58. Osawa H, Onuma H, Ochi M, Murakami A, Yamauchi J, Takasuka T, Tanabe F, Shimizu I, Kato K, Nishida W, Yamada K, Tabara Y, Yasukawa M, Fujii Y, Ohashi J, Miki T, Makino H. Resistin SNP-420 determines its monocyte mRNA and serum levels inducing type 2 diabetes. Biochem Biophys Res Commun 2005;335:596-602.

59. Osawa H, Yamada K, Onuma H, Murakami A, Ochi M, Kawa- 
ta H, Nishimiya T, Niiya T, Shimizu I, Nishida W, Hashiramoto M, Kanatsuka A, Fujii Y, Ohashi J, Makino H. The G/G genotype of a resistin single-nucleotide polymorphism at -420 increases type 2 diabetes mellitus susceptibility by inducing promoter activity through specific binding of Sp1/3. Am J Hum Genet 2004;75:678-86.

60. Osawa H, Tabara Y, Kawamoto R, Ohashi J, Ochi M, Onuma H, Nishida W, Yamada K, Nakura J, Kohara K, Miki T, Makino H. Plasma resistin, associated with single nucleotide polymorphism -420 , is correlated with insulin resistance, lower HDL cholesterol, and high-sensitivity C-reactive protein in the Japanese general population. Diabetes Care 2007;30:1501-6.

61. Cho YM, Youn BS, Chung SS, Kim KW, Lee HK, Yu KY, Park HJ, Shin HD, Park KS. Common genetic polymorphisms in the promoter of resistin gene are major determinants of plasma resistin concentrations in humans. Diabetologia 2004;47: 559-65.

62. Xu JY, Sham PC, Xu A, Tso AW, Wat NM, Cheng KY, Fong $\mathrm{CH}$, Janus ED, Lam KS. Resistin gene polymorphisms and progression of glycaemia in southern Chinese: a 5-year prospective study. Clin Endocrinol (Oxf) 2007;66:211-7.

63. Norata GD, Ongari M, Garlaschelli K, Tibolla G, Grigore L, Raselli S, Vettoretti S, Baragetti I, Noto D, Cefalu AB, Buccianti G, Averna M, Catapano AL. Effect of the $-420 \mathrm{C} / \mathrm{G}$ variant of the resistin gene promoter on metabolic syndrome, obesity, myocardial infarction and kidney dysfunction. J Intern Med 2007;262:104-12.

64. Qasim AN, Metkus TS, Tadesse M, Lehrke M, Restine S, Wolfe ML, Hannenhalli S, Cappola T, Rader DJ, Reilly MP. Resistin gene variation is associated with systemic inflammation but not plasma adipokine levels, metabolic syndrome or coronary atherosclerosis in nondiabetic Caucasians. Clin Endocrinol (Oxf) 2009;70:698-705.

65. Hivert MF, Manning AK, McAteer JB, Dupuis J, Fox CS, Cupples LA, Meigs JB, Florez JC. Association of variants in RETN with plasma resistin levels and diabetes-related traits in the Framingham Offspring Study. Diabetes 2009;58:750-6.

66. El-Shal AS, Pasha HF, Rashad NM. Association of resistin gene polymorphisms with insulin resistance in Egyptian obese patients. Gene 2013;515:233-8.

67. Tang NP, Wang LS, Yang L, Zhou B, Gu HJ, Sun QM, Cong RH, Zhu HJ, Wang B. A polymorphism in the resistin gene promoter and the risk of coronary artery disease in a Chinese population. Clin Endocrinol (Oxf) 2008;68:82-7.

68. Bokarewa M, Nagaev I, Dahlberg L, Smith U, Tarkowski A.
Resistin, an adipokine with potent proinflammatory properties. J Immunol 2005;174:5789-95.

69. Silswal N, Singh AK, Aruna B, Mukhopadhyay S, Ghosh S, Ehtesham NZ. Human resistin stimulates the pro-inflammatory cytokines TNF-alpha and IL-12 in macrophages by NFkappaB-dependent pathway. Biochem Biophys Res Commun 2005;334:1092-101.

70. Shetty GK, Economides PA, Horton ES, Mantzoros CS, Veves A. Circulating adiponectin and resistin levels in relation to metabolic factors, inflammatory markers, and vascular reactivity in diabetic patients and subjects at risk for diabetes. Diabetes Care 2004;27:2450-7.

71. Axelsson J, Bergsten A, Qureshi AR, Heimburger O, Barany P, Lonnqvist F, Lindholm B, Nordfors L, Alvestrand A, Stenvinkel P. Elevated resistin levels in chronic kidney disease are associated with decreased glomerular filtration rate and inflammation, but not with insulin resistance. Kidney Int 2006;69: 596-604.

72. Senolt L, Housa D, Vernerova Z, Jirasek T, Svobodova R, Veigl D, Anderlova K, Muller-Ladner U, Pavelka K, Haluzik M. Resistin in rheumatoid arthritis synovial tissue, synovial fluid and serum. Ann Rheum Dis 2007;66:458-63.

73. Sunden-Cullberg J, Nystrom T, Lee ML, Mullins GE, Tokics L, Andersson J, Norrby-Teglund A, Treutiger CJ. Pronounced elevation of resistin correlates with severity of disease in severe sepsis and septic shock. Crit Care Med 2007;35:1536-42.

74. Bo S, Gambino R, Pagani A, Guidi S, Gentile L, Cassader M, Pagano GF. Relationships between human serum resistin, inflammatory markers and insulin resistance. Int J Obes (Lond) 2005;29:1315-20.

75. Kunnari A, Ukkola O, Paivansalo M, Kesaniemi YA. High plasma resistin level is associated with enhanced highly sensitive C-reactive protein and leukocytes. J Clin Endocrinol Metab 2006;91:2755-60.

76. Qi Q, Wang J, Li H, Yu Z, Ye X, Hu FB, Franco OH, Pan A, Liu $\mathrm{Y}$, Lin X. Associations of resistin with inflammatory and fibrinolytic markers, insulin resistance, and metabolic syndrome in middle-aged and older Chinese. Eur J Endocrinol 2008;159: 585-93.

77. Fargnoli JL, Sun Q, Olenczuk D, Qi L, Zhu Y, Hu FB, Mantzoros CS. Resistin is associated with biomarkers of inflammation while total and high-molecular weight adiponectin are associated with biomarkers of inflammation, insulin resistance, and endothelial function. Eur J Endocrinol 2010;162:281-8.

78. Konrad A, Lehrke M, Schachinger V, Seibold F, Stark R, Och- 
senkuhn T, Parhofer KG, Goke B, Broedl UC. Resistin is an inflammatory marker of inflammatory bowel disease in humans. Eur J Gastroenterol Hepatol 2007;19:1070-4.

79. Schaffler A, Hamer O, Dickopf J, Goetz A, Landfried K, Voelk M, Herfarth H, Kopp A, Buchler C, Scholmerich J, Brunnler T. Admission resistin levels predict peripancreatic necrosis and clinical severity in acute pancreatitis. Am J Gastroenterol 2010;105:2474-84.

80. Koch A, Gressner OA, Sanson E, Tacke F, Trautwein C. Serum resistin levels in critically ill patients are associated with inflammation, organ dysfunction and metabolism and may predict survival of non-septic patients. Crit Care 2009;13:R95.

81. Park HK, Qatanani M, Briggs ER, Ahima RS, Lazar MA. Inflammatory induction of human resistin causes insulin resistance in endotoxemic mice. Diabetes 2011;60:775-83.

82. Tarkowski A, Bjersing J, Shestakov A, Bokarewa MI. Resistin competes with lipopolysaccharide for binding to toll-like receptor 4. J Cell Mol Med 2010;14:1419-31.

83. Verma S, Li SH, Wang CH, Fedak PW, Li RK, Weisel RD, Mickle DA. Resistin promotes endothelial cell activation: further evidence of adipokine-endothelial interaction. Circulation 2003; 108:736-40.

84. Mu H, Ohashi R, Yan S, Chai H, Yang H, Lin P, Yao Q, Chen C. Adipokine resistin promotes in vitro angiogenesis of human endothelial cells. Cardiovasc Res 2006;70:146-57.

85. Calabro P, Samudio I, Willerson JT, Yeh ET. Resistin promotes smooth muscle cell proliferation through activation of extracellular signal-regulated kinase $1 / 2$ and phosphatidylinositol 3-kinase pathways. Circulation 2004;110:3335-40.

86. Shen YH, Zhang L, Gan Y, Wang X, Wang J, LeMaire SA, Coselli JS, Wang XL. Up-regulation of PTEN (phosphatase and tensin homolog deleted on chromosome ten) mediates $\mathrm{p} 38$ MAPK stress signal-induced inhibition of insulin signaling. A cross-talk between stress signaling and insulin signaling in resistin-treated human endothelial cells. J Biol Chem 2006;281: 7727-36.

87. Chen C, Jiang J, Lu JM, Chai H, Wang X, Lin PH, Yao Q. Resistin decreases expression of endothelial nitric oxide synthase through oxidative stress in human coronary artery endothelial cells. Am J Physiol Heart Circ Physiol 2010;299:H193-201.

88. Hsu WY, Chao YW, Tsai YL, Lien CC, Chang CF, Deng MC, Ho LT, Kwok CF, Juan CC. Resistin induces monocyte-endothelial cell adhesion by increasing ICAM-1 and VCAM-1 expression in endothelial cells via p38MAPK-dependent pathway. J Cell Physiol 2011;226:2181-8.
89. Manduteanu I, Pirvulescu M, Gan AM, Stan D, Simion V, Dragomir E, Calin M, Manea A, Simionescu M. Similar effects of resistin and high glucose on P-selectin and fractalkine expression and monocyte adhesion in human endothelial cells. Biochem Biophys Res Commun 2010;391:1443-8.

90. Xu W, Yu L, Zhou W, Luo M. Resistin increases lipid accumulation and CD36 expression in human macrophages. Biochem Biophys Res Commun 2006;351:376-82.

91. Rae C, Robertson SA, Taylor JM, Graham A. Resistin induces lipolysis and re-esterification of triacylglycerol stores, and increases cholesteryl ester deposition, in human macrophages. FEBS Lett 2007;581:4877-83.

92. Calabro P, Cirillo P, Limongelli G, Maddaloni V, Riegler L, Palmieri R, Pacileo G, De Rosa S, Pacileo M, De Palma R, Golino $\mathrm{P}$, Calabro R. Tissue factor is induced by resistin in human coronary artery endothelial cells by the NF-kB-dependent pathway. J Vasc Res 2011;48:59-66.

93. Jamaluddin MS, Weakley SM, Yao Q, Chen C. Resistin: functional roles and therapeutic considerations for cardiovascular disease. Br J Pharmacol 2012;165:622-32.

94. Ohmori R, Momiyama Y, Kato R, Taniguchi H, Ogura M, Ayaori M, Nakamura H, Ohsuzu F. Associations between serum resistin levels and insulin resistance, inflammation, and coronary artery disease. J Am Coll Cardiol 2005;46:379-80.

95. Wang H, Chen DY, Cao J, He ZY, Zhu BP, Long M. High serum resistin level may be an indicator of the severity of coronary disease in acute coronary syndrome. Chin Med Sci J 2009;24: 161-6.

96. On YK, Park HK, Hyon MS, Jeon ES. Serum resistin as a biological marker for coronary artery disease and restenosis in type 2 diabetic patients. Circ J 2007;71:868-73.

97. Krecki R, Krzeminska-Pakula M, Peruga JZ, Szczesniak P, Lipiec P, Wierzbowska-Drabik K, Orszulak-Michalak D, Kasprzak JD. Elevated resistin opposed to adiponectin or angiogenin plasma levels as a strong, independent predictive factor for the occurrence of major adverse cardiac and cerebrovascular events in patients with stable multivessel coronary artery disease over 1-year follow-up. Med Sci Monit 2011;17:CR26-32.

98. Momiyama Y, Ohmori R, Uto-Kondo H, Tanaka N, Kato R, Taniguchi H, Arakawa K, Nakamura H, Ohsuzu F. Serum resistin levels and cardiovascular events in patients undergoing percutaneous coronary intervention. J Atheroscler Thromb 2011;18:108-14.

99. Li L, Han JL, Mao JM, Guo LJ, Gao W. Association between serum resistin level and cardiovascular events in postmeno- 
pausal women with acute coronary syndrome undergoing percutaneous coronary intervention. Chin Med J (Engl) 2013; 126:1058-62.

100. Lee SH, Ha JW, Kim JS, Choi EY, Park S, Kang SM, Choi D, Jang Y, Chung N. Plasma adiponectin and resistin levels as predictors of mortality in patients with acute myocardial infarction: data from infarction prognosis study registry. Coron Artery Dis 2009;20:33-9.

101. Weikert C, Westphal S, Berger K, Dierkes J, Mohlig M, Spranger J, Rimm EB, Willich SN, Boeing H, Pischon T. Plasma resistin levels and risk of myocardial infarction and ischemic stroke. J Clin Endocrinol Metab 2008;93:2647-53.

102. Osawa H, Doi Y, Makino H, Ninomiya T, Yonemoto K, Kawamura R, Hata J, Tanizaki Y, Iida M, Kiyohara Y. Diabetes and hypertension markedly increased the risk of ischemic stroke associated with high serum resistin concentration in a general Japanese population: the Hisayama Study. Cardiovasc Diabetol 2009;8:60.

103. Rajpathak SN, Kaplan RC, Wassertheil-Smoller S, Cushman M, Rohan TE, McGinn AP, Wang T, Strickler HD, Scherer PE, Mackey R, Curb D, Ho GY. Resistin, but not adiponectin and leptin, is associated with the risk of ischemic stroke among postmenopausal women: results from the Women's Health Initiative. Stroke 2011;42:1813-20.

104. Prugger C, Luc G, Haas B, Morange PE, Ferrieres J, Amouyel P, Kee F, Ducimetiere P, Empana JP; PRIME Study Group. Multiple biomarkers for the prediction of ischemic stroke: the PRIME study. Arterioscler Thromb Vasc Biol 2013;33:659-66.

105. Lubos E, Messow CM, Schnabel R, Rupprecht HJ, EspinolaKlein C, Bickel C, Peetz D, Post F, Lackner KJ, Tiret L, Munzel T, Blankenberg S. Resistin, acute coronary syndrome and prognosis results from the AtheroGene study. Atherosclerosis 2007;193:121-8.

106. Efstathiou SP, Tsiakou AG, Tsioulos DI, Panagiotou TN, Pefanis AV, Achimastos AD, Mountokalakis TD. Prognostic significance of plasma resistin levels in patients with atherothrombotic ischemic stroke. Clin Chim Acta 2007;378:78-85.

107. Lee SE, Kim HS. Human resistin in cardiovascular disease. J Smooth Muscle Res 2012;48:27-35.

108. Menzaghi C, Bacci S, Salvemini L, Mendonca C, Palladino G, Fontana A, De Bonis C, Marucci A, Goheen E, Prudente S, Morini E, Rizza S, Kanagaki A, Fini G, Mangiacotti D, Federici M, De Cosmo S, Pellegrini F, Doria A, Trischitta V. Serum resistin, cardiovascular disease and all-cause mortality in patients with type 2 diabetes. PLoS One 2013;8:e64729.
109. Choi HY, Kim S, Yang SJ, Yoo HJ, Seo JA, Kim SG, Kim NH, Baik SH, Choi DS, Choi KM. Association of adiponectin, resistin, and vascular inflammation: analysis with $18 \mathrm{~F}$-fluorodeoxyglucose positron emission tomography. Arterioscler Thromb Vasc Biol 2011;31:944-9.

110. Hoefle G, Saely CH, Risch L, Koch L, Schmid F, Rein P, Aczel S, Berchtold S, Drexel H. Relationship between the adiposetissue hormone resistin and coronary artery disease. Clin Chim Acta 2007;386:1-6.

111. Pilz S, Weihrauch G, Seelhorst U, Wellnitz B, Winkelmann BR, Boehm BO, Marz W. Implications of resistin plasma levels in subjects undergoing coronary angiography. Clin Endocrinol (Oxf) 2007;66:380-6.

112. Ding Q, White SP, Ling C, Zhou W. Resistin and cardiovascular disease. Trends Cardiovasc Med 2011;21:20-7.

113. Kim M, Oh JK, Sakata S, Liang I, Park W, Hajjar RJ, Lebeche D. Role of resistin in cardiac contractility and hypertrophy. J Mol Cell Cardiol 2008;45:270-80.

114. Wang BW, Hung HF, Chang H, Kuan P, Shyu KG. Mechanical stretch enhances the expression of resistin gene in cultured cardiomyocytes via tumor necrosis factor-alpha. Am J Physiol Heart Circ Physiol 2007;293:H2305-12.

115. Rothwell SE, Richards AM, Pemberton CJ. Resistin worsens cardiac ischaemia-reperfusion injury. Biochem Biophys Res Commun 2006;349:400-7.

116. Takeishi Y, Niizeki T, Arimoto T, Nozaki N, Hirono O, Nitobe J, Watanabe T, Takabatake N, Kubota I. Serum resistin is associated with high risk in patients with congestive heart failure: a novel link between metabolic signals and heart failure. Circ J 2007;71:460-4.

117. Frankel DS, Vasan RS, D’Agostino RB Sr, Benjamin EJ, Levy D, Wang TJ, Meigs JB. Resistin, adiponectin, and risk of heart failure the Framingham offspring study. J Am Coll Cardiol 2009;53:754-62.

118. Butler J, Kalogeropoulos A, Georgiopoulou V, de Rekeneire N, Rodondi N, Smith AL, Hoffmann U, Kanaya A, Newman AB, Kritchevsky SB, Vasan RS, Wilson PW, Harris TB; Health ABC Study. Serum resistin concentrations and risk of new onset heart failure in older persons: the health, aging, and body composition (Health ABC) study. Arterioscler Thromb Vasc Biol 2009;29:1144-9.

119. Bhalla V, Kalogeropoulos A, Georgiopoulou V, Butler J. Serum resistin: physiology, pathophysiology and implications for heart failure. Biomark Med 2010;4:445-52. 